\title{
EKSISTENSI KINERJA REKSADANA SYARIAH PADA ERA NEW NORMAL
}

\author{
Titi Rapini ${ }^{1}$, Umi Farida ${ }^{2}$ \& Rizki Listyono Putro ${ }^{3}$ \\ ${ }_{1,2, \& 3}$ Fakultas Ekonomi, Universitas Muhammadiyah Ponorogo \\ Email:titi.rapini@gmail.com,umifarida899@gmail.com,rizkylistyono@gmail.com
}

\begin{abstract}
ABSTRAK
Penelitian ini bertujuan meninjau perkembangan investasi reksadana syariah yang terdaftar dalam Otoritas Jasa Keuangan pada periode era new normal. Data yang dianalisis pada penelitian ini yaitu data sekunder, serta pengambilan sampel menggunakan purposive sampling. Teknik analisis yang digunakan dalam penelitian ini adalah deskriptif dengan pendekatan kuantitatif. Berdasarkan hasil penelitian yang telah dijabarkan, eksistensi kinerja reksadana syariah tumbuh positif pada era new normal. Hal itu berdasarkan: (1) Tingkat return reksadana positif ditinjau dari Compound Annual Growth Rate (CAGR), dalam CAGR 1Y peningkatan paling tinggi sebesar $+63.97 \%$ dan paling rendah $+2.59 \%$, (2) Tingkat kerugian yang paling tinggi periode satu tahun terakhir ditinjau dari drawdown $1 \mathrm{Y}$ paling rendah yaitu sebesar $0,01 \%$ dan drawdown tertinggi sebesar $-19.30 \%$, (3) Terdapat peningkatan jumlah dana yang dikelola ditinjau dari nilai AUM (Asset Under Management) $1 \mathrm{Y}$ pertumbuhan paling tinggi $+536.31 \mathrm{~B}$ dan penurunan paling rendah $-152.71 \mathrm{~B}$, (4) Pertumbuhan nilai pasar reksadana saat ini, ditinjau dari Net Asset Value (NAV) 1Y seluruh sampel tumbuh positif dengan tambahan paling tinggi sebesar +753.65 , dan paling rendah +22.20 .
\end{abstract}

Kata Kunci : Reksadana Syariah, CAGR, Drawdown, AUM, NAV.

\begin{abstract}
This study aims to review the development of sharia mutual fund investments registered with the Financial Services Authority in the new normal era. The data analyzed in this study are secondary data, as well as sampling using purposive sampling. The analytical technique used in this research is descriptive with a quantitative approach. Based on the research results that have been described, the existence of sharia mutual fund performance grows positively in the new normal era. This is based on: (1) a positive mutual fund return rate in terms of the Compound Annual Growth Rate (CAGR), in CAGR $1 Y$ the highest increase is $+63.97 \%$ and the lowest is $+2.59 \%$, (2) the highest loss rate in the last one year period in terms of the lowest $1 Y$ drawdown of $0.01 \%$ and the highest drawdown of $19.30 \%$, (3) there was an increase in the amount of funds managed in terms of AUM (assets under management) $1 Y$ the highest growth of $+536.31 \mathrm{~B}$ and the lowest decrease - $152.71 \mathrm{~B}$, (4) the current market value growth of mutual funds, in terms of Net Asset Value (NAV) 1Y, all samples grew positively with the highest addition of +753.65 , and the lowest of +22.20 .
\end{abstract}

Keywords : Sharia Mutual Funds, CAGR, Drawdown, AUM, NAV. 


\section{PENDAHULUAN}

Di era digital saat ini kita dapat memperoleh informasi apapun dengan mudah dan cepat, berkaitan dengan informasi keuangan sudah sangat berkembang terbukti dengan maraknya platform atau unicorn menawarkan berbagai investasi keuangan. Ditunjang dengan mayoritas penduduk aktif yang milenial dengan kesadaran tentang literasi keuangan tentang kesadaran akan pentingnya investasi, maka investasi digital di Indonesia tumbuh positif. Pada saat pandemi covid 19 justru perkembangan pasar modal di Indonesia semakin besar. Jenis investasi yang berkembang saat ini meliputi saham, reksadana, peer to peer lending dan lain sebagainya.

Sebagaimana diketahui mayoritas penduduk Indonesia adalah Islam, masuknya syariat Islam dalam pengelolaan keuangan diharapkan dapat menjadikan pilihan bagi masyarakat untuk menghilangkan praktik riba. Hal itu merupakan salah satu solusi persoalan bagi masyarakat yang menghindari praktik riba dalam berinvestasi. Sesuai dengan penjelasan Endraswati (2016), penilaian keberhasilan investasi tidak saja ditentukan oleh tingkat pengembalian return yang tinggi, namun juga harus mempertimbangkan kepuasan spiritual. Kecenderungan investasi seperti ini disebut dengan ethical investment yakni investasi yang memiliki tanggung jawab secara sosial dengan menggunakan pertimbangan etika dalam investasi tersebut atau disebut dengan ethical screening.

Fakta dilapangan ada beberapa masalah yang terjadi, yaitu tidak semua calon investor menguasai ilmu pasar modal, waktu yang cukup, serta keterbatasan mendapatkan informasi perusahaan. Salah satu pilihan investasi yang paling tepat untuk berbagai kendala tersebut, yaitu melalui reksadana. Hal itu sesuai dengan Qamruzzaman (2014), menjelaskan reksadana mempunyai kelebihan dalam hal fleksibilitas, diversifikasi, serta likuiditas. Reksadana merupakan jawaban untuk investor pemula, yang belum memiliki pengalaman, ilmu investasi serta waktu yang terbatas.

Reksadana merupakan perusahaan yang menyediakan pengelolaan berbagai investasi berbentuk portofolio ke dalam surat berharga seperti : saham, obligasi, dan instrumen pasar uang sepenuhnya akan dipertanggung jawabkan oleh manajer investasi. Martalena \& Maya (2011), menjelaskan bahwa reksadana diklasifikasikan menjadi reksadana pasar uang, reksadana saham, reksadana pendapatan tetap dan reksadana campuran. Serta penjelasan dari Kasmir (2013), pasar modal sebagaimana pasar pada umumnya adalah suatu tempat untuk bertemunya para penjual dan pembeli untuk melakukan transaksi dalam rangka memperoleh modal, salah satu pilihan investasi dipasar modal melalui reksadana.

Reksadana dalam operasional kerjanya, dibagi menjadi reksadana konvensional dan reksadana syariah. Perbedaan dari reksadana konvensional maupun reksadana syariah terletak pada pembagian alokasi modal instrumen investasinya, yaitu standar operasional harus sesuai dengan pedoman agama Islam dan pembuatan portofolio investasi harus mengedepankan aspek halal. Perkembangan reksadana syariah untuk kedepannya sangat menjanjikan, ada sebagian masyarakat yang tidak hanya mempertimbangkan return yang tinggi, namun juga mempertimbangkan prinsip kehidupan yang tidak melanggar kaidah syariah dalam berinvestasinya.

Fakta tersebut didukung penjelasan oleh Syafrida et al (2014), menyatakan bahwa calon investor dalam berinvestasi pasti mempertimbangan finansial aspek imbal hasil (return) dan resiko (risk). Tetapi sebagian calon investor dalam berinvestasi tidak hanya mempertimbangkan aspek aspek imbal hasil (return) dan resiko (risk), juga ada yang mempertimbangkan nilai-nilai yang dianutnya agar tidak bertentangan dengan prinsip yang dianutnya. Ditinjau dari capaian kinerjanya, reksadana syariah bisa bersaing dengan reksadana konvensional. Hal tersebut 
dijelaskan oleh Muliaman D. Hadad bahwa industri keuangan syariah di Indonesia memiliki potensi yang sangat besar untuk berkembang karena masih terbatasnya pangsa pasar industri keuangan syariah di Indonesia dibandingkan dengan industri keuangan konvensional.

Fakta tersebut sesuai dengan hasil penelitian dari Hamzah dan Yohanes (2014), hasil penelitiannya menjelaskan bahwa tidak ditemukan perbedaan signifikan capaian prestasi kinerja antara reksadana jenis saham konvensional maupun reksadana jenis saham syariah, serta masing-masing memiliki kelebihan dan kelemahannya. Berikut data pertumbuhan jumlah reksadana syariah dan konvensional di Indonesia periode 2010 sampai 2020.

Tabel 1. Perbandingan Jumlah Reksadana Konvensional dan Syariah

\begin{tabular}{cccc}
\hline & Reksadana Syariah & Reksadana Konvensional & Reksadana Total \\
\hline 2010 & 48 & 564 & 612 \\
\hline 2011 & 50 & 596 & 646 \\
\hline 2012 & 58 & 696 & 754 \\
\hline 2013 & 65 & 758 & 823 \\
\hline 2014 & 74 & 820 & 894 \\
\hline 2015 & 93 & 998 & 1091 \\
\hline 2016 & 136 & 1289 & 1425 \\
\hline 2017 & 182 & 1595 & 1777 \\
\hline 2018 & 224 & 1875 & 2099 \\
\hline 2019 & 265 & 1916 & 2181 \\
\hline 2020 & 289 & 1930 & 2219 \\
\hline
\end{tabular}

Sumber : Direktorat Pasar Modal Syariah, Otoritas Jasa Keuangan (2020)

Berdasarkan data di atas, setiap tahunnya terdapat pertumbuhan jumlah reksadana syariah maupun konvensional. Pada tahun 2010 terdapat 612 reksadana, maka pada tahun 2020 telah bertambah menjadi 2219 reksadana jenis konvensional dan syariah. Padahal pada awal tahun 2020 terjadi pandemi covid 19 yang berakibat lesunya perekonomian di Indonesia, hal tersebut tidak menghambat pertumbuhan jumlah reksadana. Berikut data pertumbuhan Nilai Aktiva Bersih (NAB) reksadana di Indonesia periode 2015 sampai 2020.

Tabel 2. Perbandingan Nilai Aktiva Bersih (NAB) Reksadana

\begin{tabular}{cc}
\hline Tahun & NAB Reksadana Syariah (Rp triliun) \\
\hline 2016 & 14.91 \\
\hline 2017 & 28.31 \\
\hline 2018 & 34.49 \\
\hline 2019 & 53.74 \\
\hline 2020 & 74.37 \\
\hline 2021 & 77.51 \\
\hline
\end{tabular}

Sumber: Direktorat Pasar Modal Syariah, Otoritas Jasa Keuangan (2020)

Tabel di atas menunjukkan perkembangan reksadana syariah di Indonesia mulai tahun 2016 sampai dengan tahun 2021 yang setiap tahunnya menunjukkan trend yang positif dari segi jumlah reksadana dan besaran nilai $\mathrm{NAB}$ (nilai aktiva bersih dalam Rp Triliun). Pada tahun 2016 terdapat 136 reksadana dengan
Nilai Aktiva Bersih (NAB) 14,91, setiap tahunnya meningkat hingga pada tahun 2021 meningkat terdapat 291 reksadana dengan NAB 77,51. Pertumbuhan Nilai Aktiva Bersih (NAB) reksadana syariah tertinggi terjadi pada rentang tahun 2019 sampai 2020, dan pertumbuhan jumlah reksadana syariah tertinggi pada rentang tahun 2018- 
2019. Padahal pada awal quartal 1 tahun 2020 terjadi pandemi yang menyebabkan perekonomian nasional resesi, tetapi perkembangan jumlah reksadana serta Nilai Aktiva Bersih (NAB) tetap meningkat.

Pada periode awal tahun 2020 terjadi pandemi yang menyebabkan pertumbuhan perekonomian nasional terganggu, justru reksadana syariah mengalami pertumbuhan Nilai Aktiva Bersih (NAB) periode 20192021 sebesar 23.77 dan jumlah reksadana mengalami pertambahan 26.

Pertumbuhan reksadana di era new normal merupakan fenomena yang menarik, selama pemerintah menetapkan new normal justru lebih banyak masyarakat ingin berinvestasi khususnya direksadana syariah. Tingginya minat masyarakat investasi, maka calon investor perlu melakukan seleksi terhadap reksadana saham dilakukan dengan melalui pengamatan terhadap kinerja reksadana saham tersebut. Kinerja reksadana secara sederhana merupakan kemampuan manajer investasi untuk menghasilkan return yang sesuai diharapkan investor, sehingga bagi investor memilih reksadana yang mampu menghasilkan return sesuai resiko investasi sangat penting. Walaupun belum pasti kalau kinerja reksadana memiliki kinerja bagus ditahun-tahun sebelumnya akan berkinerja lebih bagus yang akan datang, tetapi reksadana memiliki kinerja bagus dimasa lalu memiliki peluang tinggi berkinerja bagus pada masa yang akan datang.

Setiap jenis reksadana memiliki kinerja yang berbeda-beda, tergantung bagaimana kinerja perusahaan manajer investasinya mengelola. Manajer investasi yang bertindak sebagai pengelola reksadana dalam pengelolaannya berusaha untuk dapat membentuk suatu portofolio yang optimal dengan cara mengkombinasikan aktiva yang dimilikinya. Portofolio optimal yang dimaksud ialah portofolio yang memiliki kombinasi expected return dan resiko yang terbaik.
Bagi calon investor sangat penting menganalisis dari beberapa perusahaan manajer investasi reksadana berkinerja paling baik. Suatu manajer investasi reksadana bisa dikatakan berkinerja baik jika mampu memberikan tingkat return yang tinggi dengan resiko yang wajar atau bahkan rendah bagi calon investor. Adanya laporan kinerja reksadana syariah Indonesia yang sudah bisa diakses masyarakat umum, maka diharapkan mampu memberikan informasi yang objektif tentang kondisi kinerja reksadana tersebut. Dalam membangun kepercayaan selain layanan yang prima dan penjelasan yang komprehensif, laporan akan bagaimana dana nasabah dikelola juga berperan penting. Laporan yang memuat informasi pengelolaan dana disebut Fund Fact Sheet (FFS). Umumnya Fund Fact Sheet (FFS) bisa ditemukan di dalam situs yang dikelola oleh Manajer Investasi dan Agen Penjual.

Namun ada juga Manajer Investasi yang melampirkan cetak Fund Fact Sheet (FFS) yang dikirimkan ke nasabah bersamaan dengan laporan perkembangan saldo setiap bulan. Namun, seiring dengan jumlah investor yang semakin banyak, biaya cetak dan kirim yang semakin mahal serta perkembangan teknologi informasi, kini banyak yang beralih menggunakan situs dan aplikasi pada smartphone. Informasi Jumlah Dana Kelolaan dan Unit Penyertaan (AUM), Informasi Harga dan Kinerja Reksa Dana (NAB), (CAGR), dan drawdown (Rudiyanto, 2015). Berdasarkan pemaparan permasalahan dan kondisi perkembangan reksadana syariah di Indonesia, maka akan melakukan penelitian yang berjudul "Eksistensi kinerja reksadana syariah diera new normal".

\section{TINJAUAN PUSTAKA}

\section{Pengertian Reksadana}

Hariyani dan Serfianto (2010), menjelaskan bahwa reksadana merupakan tempat untuk menghimpun modal atau dana dari masyarakat sebagai pemodal, selanjutnya di investasikan dalam portofolio efek oleh manajer investasi. Para pemodal 
reksadana tidak membeli efek di pasar modal, tetapi akan dikelola oleh manajer investasi reksadana. Manajer investasi akan mengelola modal-modal yang dihimpun dari masyarakat untuk membeli efek-efek yang dinilai menguntungkan sesuai tujuan dan karakteristik reksadana. Bila modal yang diinvestasikan oleh manajer investasi reksadana mendapatkan keuntungan, maka keuntungan tersebut akan dikembalikan kepada para pemodal sesuai kesepakatan yang dinamakan return. Dari pihak manajer investasi akan mendapat uang jasa (fee) sesuai kesepakatan.

Reksadana yang berkembang di Indonesia ada konvensional dan syariah. Reksadana syariah bersumber dari peraturan Fatwa DSN Nomor : 20/DSN-MUI/IX/2000 tanggal 18 April 2000 tentang Pedoman Pelaksanaan Investasi untuk Reksadana Syariah, telah didefinisikan bahwa reksadana syariah merupakan reksadana yang operasionalnya berdasarkan ketentuan dan prinsip syariah Islam, baik dalam bentuk akad antara pemodal sebagai milik harta (shahib al-mal/rabb al-maal), dengan manajer investasi sebagai wakil shahib almal, maupun manajer investasi sebagai wakil shahib al-mal dengan pengguna investasi.

Sutedi (2011), menjelaskan bahwa beberapa jenis reksadana yaitu:

1. Reksadana pasar uang (money market funds), menjalankan investasi untuk efek yang sifatnya utang pada jatuh tempo kurang dari 1 tahun. Tujuan utamanya melindungi likiuditas dan modal investasi dari fluktuasi ekonomi.

2. Reksadana pendapatan tetap (fixed income funds), menjalankan investasi kurang lebih $80 \%$ aktivanya dialokasikan untuk efek bersifat utang. Reksadana pendapatan tetap akan menanggung resiko yang cukup besar daripada reksadana pasar uang. Tujuan utamanya untuk mendapatkan tingkat pengembalian (return) yang stabil

3. Reksadana saham (equity funds), menjalankan investasi kurang lebih $80 \%$ dari aktivanya dialokasikan pada efek bersifat ekuitas. Investasi reksadana saham akan memiliki resiko lebih besar daripada reksadana pasar uang dan reksadana pendapatan tetap, tetapi akan mendapatkan tingkat pengembalian yang besar.

4. Reksadana campuran (Mix Funds), menjalankan investasi pada efek yang bersifat ekuitas dan efek bersifat utang.

Kemajuan investasi dalam reksadana bisa dianalisis dari laporan kinerja reksadana setiap periodenya. Kinerja reksadana menjelaskan kemampuan suatu produk reksadana untuk menghasilkan return atau tingkat pengembalian yang kemudian diberikan kepada para investornya (Bitomo dan Muharam, 2016).

Adanya analisis kemajuan reksadana terkait kinerjanya, maka akan membantu para investor masyarakat dalam menentukan reksadana yang bagus untuk dipilih sebagai investasinya. Analisis pada kinerja reksadana akan mampu dijadikan literasi untuk seluruh pihak yang berkepentingan agar tetap menentukan performa yang baik dari reksadana.

Idris (2020), menjelaskan bahwa sebelum menginvestasikan modal ke reksadana hal yang perlu dianalisa antara lain berdasarkan jumlah dana kelola atau Asset Under Management (AUM), Compound Annual Growth Rate (CAGR), drawdown dan Nilai Aktiva Bersih (NAB)-nya. Compounded Annual Growth Rate (CAGR) atau laju pertumbuhan tahunan majemuk yang merupakan besar pertumbuhan rata-rata secara majemuk atas investasi pada periode tertentu, periode 1 tahun, 3 tahun atau lima tahun. Compounded Annual Growth Rate (CAGR) digunakan untuk menghitung besaran investasi akan bertumbuh pada setiap tahunnya, rumus Compounded Annual Growth Rate (CAGR) menggunakan formula berikut:

$$
\mathrm{CAGR}=\left(\frac{E V}{B V}\right)^{2}-1
$$

Keterangan $: \mathrm{EV}=$ nilai akhir, 


$$
\begin{aligned}
& \mathrm{BV}=\text { nilai awal, } \\
& \mathrm{N}=\text { jumlah tahun, }
\end{aligned}
$$

Idris (2020) menjelaskan bahwa drawdown merupakan tingkat kerugian yang paling besar produk reksadana pada rentang waktu tertentu, atau selisih paling tinggi diantara tingkat penurunan kinerja reksadana dari titik puncak dengan titik terendah. Sama seperti sharpe ratio, nilai drawdown juga bisa dipengaruhi oleh time frame.

Adapun rumus menghitung drawdown sebagai berikut,

MDD $=$ (nilai paling dasar - nilai paling

$$
\text { puncak) / Nilai paling puncak * } 100
$$

Pengukuran kinerja reksadana dalam penelitian ini juga menggunakan metode berdasarkan pertumbuhan AUM (Asset Under Management). Asset Under Management (AUM) merupakan besarnya dana kelolaan suatu perusahaan investasi (reksadana) yang bisa dijadikan acuang tentang seberapa besar kepercayaan para pemilik modal (masyarakat) kepada suatu reksadana. Asset Under Management (AUM) juga sering disebut dana kelolaan, yang merupakan dana yang dikelola oleh reksadana tersebut. Semakin besar nilai dana kelolaan suatu reksadana, maka tingkat kepercayaan pemilik modal terhadap kualitas kinerja reksadana juga lebih terpercaya.

Idris (2020) menjelaskan Asset Under Management (AUM) adalah jumlah dana yang dikelola dalam suatu produk reksadana. Besarnya Asset Under Management (AUM) menandakan tingginya kepercayaan investor terhadap manajer investasi reksadana konvensional maupun syariah. Pada kinerja reksadana, besaran nilai Asset Under Management (AUM) sering sejalan dengan kinerja manajemen dan pengalaman manajemen. Tetapi, investor sering menganggap perbandingan aliran masuk investasi dan AUM yang lebih tinggi sebagai indikator mutu dan pengalaman manajemen. Cara mengakumulasikan aset yang dikelola perusahaan investasi berbedabeda. Aset yang dikelola oleh manajemen investasi pada aliran uang investor yang keluar serta masuk dana tertentu sehingga bisa naik turun setiap hari.

Selanjutnya kinerja aset, apresiasi modal dan reinvestasi dividen akan meningkatkan Asset Under Management (AUM). Total aset perusahaan yang dikelola bisa meningkat ketika pelanggan baru dan aset mereka diperoleh. Asset Under Management (AUM) juga mengalami penurunan jika berkurangnya harga pasar karena penurunan aliran investor, penutupan dana, dan kerugian investasi.

Net Asset Value merupakan nilai pasar reksadana saat ini. Indikator nilai $\mathrm{Net}$ Asset Value (NAV) dari nilai surat berharga (surat berharga pasar uang, obligasi, saham, serta deposito) yang terdapat pada reksadana, ditambah dividen serta kupon obligasi, dikurangi biaya operasional reksa dana (biaya Manager Investasi, biaya Bank Kustodian, dan biaya lain-lain). Para pemilik modal akan berinvestasi reksadana maka akan membeli unit penyertaan. Unit penyertaan merupakan surat keterangan yang menjelaskan suatu kepemilikan reksadana. Jumlah unit penyertaan akan berubah seiring dengan penjualan atau pembelian reksadana. Unit penyertaan ada harganya, yaitu Nilai Aktiva Bersih (NAB) atau Net Asset Value (NAV). Jumlah unit penyertaan yang Anda peroleh tergantung dari harga NAB/NAV per unit pada hari dimana membeli reksadana tersebut. Naik turunnya nilai investasi di Reksadana ditentukan oleh perkembangan harga Nilai Aktiva Bersih (NAB) per unit.

Dalam mengnalisis kinerja reksadana memerlukan informasi Nilai Aktiva Bersih (NAB) perunit. Rodoni (2009), menjelaskan Net Asset Value (NAV) atau Nilai Aktiva Bersih (NAB) berasal dari hasil penjumlahan nilai seluruh portofolio yang terdiri dari obligasi, saham , dan instrumen pasar modal, maupun uang kas, deposito, instrumen pasar uang lainnya, ditambah dengan tagihan kepada broker, piutang dividen, piutang bunga, dan piutang lainya. Selanjutnya dikurangkan dengan kewajibannya yang terdiri dari pinjaman, kewajiban ke broker, 
kewajiban atas fee broker yang belum dibayar, kewajiban atas fee kustodian yang belum dibayar, dan amortisasi biaya pendirian jika ada. Nilai Aktiva Bersih (NAB) atau Net Asset Value (NAV) merupakan salah satu tolak ukur dalam memantau hasil portofolio reksadana. Net Asset Value (NAV) dapat di formulasikan sebagai berikut :

$$
\mathrm{NAV}_{\mathrm{t}}=\left(\mathrm{MVA}_{\mathrm{t}}-\mathrm{LIAB} / \mathrm{NSO}_{\mathrm{t}}\right)
$$

Keterangan :
$\mathrm{NAV}_{\mathrm{t}}=$ Nilai Aktiva Bersih pada periode $\mathrm{t}$

$\mathrm{MVA}_{\mathrm{t}}=$ Total Nilai Pasar Aktiva pada periode

LIAB $_{t}=$ Total Kewajiban Reksadana pada periode $\mathrm{t}$

$\mathrm{NSO}_{\mathrm{t}}=$ Jumlah unit penyertaan beredar pada periode $\mathrm{t}$

Berdasarkan penjelasan teori dan beberapa kriteria yang ditentukan, maka diambil sampel berjumlah 22 reksadana syariah sebagai berikut:

Tabel 3. Sampel Reksadana Syariah

\begin{tabular}{|c|c|c|}
\hline No & Reksadana syariah & Jenis Produk \\
\hline 1. & Sucorinvest Sharia Money Market Fund & Pasar Uang \\
\hline 2. & BNP Paribas Pesona Syariah & Saham \\
\hline 3. & Eastpring syariah fixed income amanah kelas A & Obligasi \\
\hline 4. & Sucorinvest sharia equity fund & Saham \\
\hline 5. & BNI-AM Dana Lancar Syaariah & Pasar uang \\
\hline 6. & Majoris sukuk negara Indonesia & Obligasi \\
\hline 7. & Manulife syariah sektoral amanah kelas A & Saham \\
\hline 8. & Schroder Syariah Balanced Fund & Campuran \\
\hline 9. & Batavia dana saham syariah & Saham \\
\hline 10. & Trim syariah saham & Saham \\
\hline 11. & Majoris pasar uang syariah Indonesia & Pasar uang \\
\hline 12. & Principal Islamic Equity Growth Syariah & Saham \\
\hline 13. & Schroder Dana Likuid Syariah & Pasar uang \\
\hline 14. & Bahana MES Syariah Fund Kelas G & Obligasi \\
\hline 15. & Mandiri pasar uang syariah ekstra & Pasar Uang \\
\hline 16. & BNI-AM Dana Pendapatan tetap Syariah Ardhani & Obligasi \\
\hline 17. & Manulife dana kas syariah & Pasar uang \\
\hline 18. & Mandiri investa dana syariah & Obligasi \\
\hline 19. & Simas syariah unggulan & Saham \\
\hline 20. & Danareksa indeks syariah & Saham \\
\hline 21. & Mandiri investa syariah berimbang & Campuran \\
\hline 22. & Avrist amar balanced amar syariah & Campuran \\
\hline
\end{tabular}

Sumber : Direktorat Pasar Modal Syariah, Otoritas Jasa Keuangan (2020)

\section{METODE PENELITIAN}

Sumber data penelitian didapatkan dari laporan prospectus dan fun fact sheet yang diterbitkan reksadana syariah pada periode tertentu dipublikasikan setiap entitas reksadana. Informasi data tersebut berasal dari Badan Pengawas Pasar Modal (Bapepam) yang dikelola oleh Otoritas Jasa Keuangan (OJK) berdasarkan periode tahun 
2015-2020, update data penelitian terbaru bulan April 2021.

\section{Metode Pengumpulan Data}

Metode pengumpulan data dalam penelitian ini yaitu observasi dan dokumentasi.

\section{Populasi dan Sampel}

Penelitian ini menggunakan populasi reksadana syariah di Bursa Efek Indonesia, sampel peneitian diambil dengan beberapa kriteria tertentu yaitu:

1. Reksadana dalam pengelolaan dananya atau modalnya menerapkan prinsip syariah.

2. Reksadana syariah jenis produk pasar uang, saham, obligasi, dan campuran.
3. Reksadana syariah yang terdaftar secara resmi dan aktif tercatat di Badan Pengawas Pasar Modal (Bapepam).

4. Reksadana syariah yang menerbitkan laporan keuangan tahunannya.

\section{HASIL PENELITIAN DAN PEMBAHASAN}

Berdasarkan tinjauan teori yang dijelaskan, maka pengukuran kinerja reksadana saham syariah berdasarkan Compound Annual Growth Rate (CAGR), Drawdown, total AUM (Asset Under Management) dan Net Asset Value (NAV) sebagai berikut:

Compound Annual Growth Rate (CAGR).

Tabel 4. Compound Annual Growth Rate (CAGR) Reksadana Syariah

\begin{tabular}{|c|c|c|c|c|}
\hline No & REKSADANA SYARIAH & $1 \mathrm{Y}$ & $3 \mathbf{Y}$ & $5 \mathrm{Y}$ \\
\hline 1 & Sucorinvest Sharia Money Market Fund & $+8.45 \%$ & $-1.05 \%$ & $+0.94 \%$ \\
\hline 2 & BNP Paribas Pesona Syariah & $+19.82 \%$ & $-3.33 \%$ & $-0.78 \%$ \\
\hline 3 & $\begin{array}{l}\text { Eastpring syariah fixed income amanah } \\
\text { kelas A }\end{array}$ & $+12.23 \%$ & $+8.05 \%$ & - \\
\hline 4 & Sucorinvest sharia equity fund & $+63.97 \%$ & $+6.01 \%$ & $+16.13 \%$ \\
\hline 5 & BNI-AM Dana Lancar Syariah & $+4.51 \%$ & $+4.91 \%$ & $+5.22 \%$ \\
\hline 6 & Majoris sukuk negara Indonesia & $+10.02 \%$ & $+6.38 \%$ & - \\
\hline 7 & Manulife syariah sektoral amanah kelas A & $+31.56 \%$ & $-3.97 \%$ & $-1.11 \%$ \\
\hline 8 & Schroder Syariah Balanced Fund & $+8.45 \%$ & $-1.05 \%$ & $+0.94 \%$ \\
\hline 9 & Batavia dana saham syariah & $+14.69 \%$ & $-5.23 \%$ & $-2.34 \%$ \\
\hline 10 & Trim syariah saham & $+27.61 \%$ & $+1.60 \%$ & $+2.39 \%$ \\
\hline 11 & Majoris pasar uang syariah Indonesia & $+3.12 \%$ & $+4.88 \%$ & - \\
\hline 12 & Principal Islamic Equity Growth Syariah & $+11.56 \%$ & $-6.87 \%$ & $-4.22 \%$ \\
\hline 13 & Schroder Dana Likuid Syariah & $+2.59 \%$ & - & - \\
\hline 14 & Bahana MES Syariah Fund Kelas G & $+10.51 \%$ & $+7.36 \%$ & - \\
\hline 15 & Mandiri pasar uang syariah ekstra & $+3.91 \%$ & - & - \\
\hline 16 & $\begin{array}{l}\text { BNI-AM Dana Pendapatan tetap Syariah } \\
\text { Ardhani }\end{array}$ & $+14.06 \%$ & $+9.83 \%$ & - \\
\hline 17 & Manulife dana kas syariah & $+4.35 \%$ & - & - \\
\hline 18 & Mandiri investa dana syariah & $+6.49 \%$ & $+4.89 \%$ & $+4.90 \%$ \\
\hline 19 & Simas syariah unggulan & $+3.10 \%$ & $-20.30 \%$ & $-8.07 \%$ \\
\hline 20 & Danareksa indeks syariah & $+7.51 \%$ & $-7.77 \%$ & $-3.72 \%$ \\
\hline 21 & Mandiri investa syariah berimbang & $+7.49 \%$ & $+4.57 \%$ & - \\
\hline
\end{tabular}




\begin{tabular}{|c|c|c|c|c|}
\hline 22 & Avrist balanced amar syariah & $+7.46 \%$ & $+0.15 \%$ & $+0.75 \%$ \\
\hline
\end{tabular}

\section{Sumber: https://bibit.id (2020)}

Tabel di atas merupakan rangkuman kinerja reksadana berdasarkan Compound Annual Growth Rate (CAGR), CAGR dapat menganalisa seberapa baik, atau buruk, kinerja suatu saham atau reksadana dalam suatu periode. Makin tinggi keuntungan yang bisa diperoleh tentunya lebih baik, dan meninjau konsistensi nya selama 3 atau 5 tahun kebelakang seberapa besar return per tahun nya atau Compound Annual Growth Rate (CAGR) nya. Ditinjau Compound Annual Growth Rate (CAGR) 5Y, sampel reksadana syariah yang paling baik yaitu Sucorinvest sharia equity fund memiliki pertumbuhan paling besar yaitu $16.13 \%$, BNI-AM Dana Lancar Syariah $+5.22 \%$, Mandiri investa dana syariah $+4.90 \%$, Trim syariah saham $+2.39 \%$, Sucorinvest Sharia Money Market Fund $+0.94 \%$, Schroder Syariah Balanced Fund $+0.94 \%$, dan Avrist balanced amar syariah $+0.75 \%$.

Adapun reksadana yang tumbuh negatif yang paling besar adalah simas syariah unggulan $-8.07 \%$, Principal Islamic Equity Growth Syariah $-4.22 \%$, dan Danareksa indeks syariah $-3.72 \%$. Pada awal tahun 2020 situasi ekonomi di Indonesia mengalami tekanan, berdasarkan data Compound Annual Growth Rate (CAGR) 1Y dari seluruh sampel tumbuh positif. Sampel yang memiliki pertumbuhan paling tinggi yaitu reksadana syariah Sucorinvest sharia equity fund, mampu mencetak Compound Annual Growth Rate (CAGR) 1Y sebesar $+63.97 \%$, Manulife syariah sektoral amanah kelas A $+31.56 \%$, dan BNP Paribas Pesona Syariah $+19.82 \%$. Fakta dilapangan bahwa reksadana syariah mendapatkan return lebih tinggi dibandingkan dengan kondisi ISHG saat ini.

Temuan ini didukung dengan pendapat dari Lohana (2013) menjelaskan kondisi reksadana keuangan pada negara berkembang return-nya memiliki indeks return yang lebih tinggi dibandingkan pasar meskipun tidak terlalu tinggi. Serta Qamruzzaman (2014), menyatakan bahwa pertumbuhan reksadana lebih tinggi dari return pasar dan menawarkan keuntungan atas diversifikasi, market timing, dan penyeleksian saham.

\section{Drawdown}

Tabel 5. Drawdown Reksadana Syariah

\begin{tabular}{|c|c|c|c|c|}
\hline NO & REKSADANA SYARIAH & $1 Y$ & $3 \mathbf{Y}$ & $5 Y$ \\
\hline 1 & $\begin{array}{l}\text { Sucorinvest Sharia Money Market } \\
\text { Fund }\end{array}$ & - & - & - \\
\hline 2 & BNP Paribas Pesona Syariah & $-13.22 \%$ & $-42.74 \%$ & $-46.16 \%$ \\
\hline 3 & $\begin{array}{l}\text { Eastpring syariah fixed income } \\
\text { amanah kelas A }\end{array}$ & $-1.68 \%$ & $-6.59 \%$ & - \\
\hline 4 & Sucorinvest sharia equity fund & $-9.55 \%$ & $-40.58 \%$ & - \\
\hline 5 & BNI-AM Dana Lancar Syariah & $-0.01 \%$ & $-0.06 \%$ & $-0.06 \%$ \\
\hline 6 & Majoris sukuk negara Indonesia & $-2.45 \%$ & $-5.36 \%$ & $-5.71 \%$ \\
\hline 7 & $\begin{array}{l}\text { Manulife syariah sektoral amanah } \\
\text { kelas A }\end{array}$ & $-14.30 \%$ & $-46.30 \%$ & $-50.77 \%$ \\
\hline 8 & Schroder Syariah Balanced Fund & $-9.00 \%$ & $-22.33 \%$ & $-23.82 \%$ \\
\hline 9 & Batavia dana saham syariah & $-15.42 \%$ & $-43.08 \%$ & $-44.95 \%$ \\
\hline 10 & Trim syariah saham & $-15.51 \%$ & $-43.31 \%$ & - \\
\hline 11 & Majoris pasar uang syariah Indonesia & $-0.33 \%$ & - & - \\
\hline 12 & $\begin{array}{l}\text { Principal Islamic Equity Growth } \\
\text { Syariah }\end{array}$ & $-17.12 \%$ & $-43.45 \%$ & $-48.56 \%$ \\
\hline 13 & Schroder Dana Likuid Syariah & $-0.15 \%$ & - & - \\
\hline
\end{tabular}




\begin{tabular}{clllc}
\hline 14 & Bahana MES Syariah Fund Kelas G & $-1.95 \%$ & $-7.64 \%$ & $-8.08 \%$ \\
\hline 15 & Mandiri pasar uang syariah ekstra & $-0.03 \%$ & - & - \\
\hline 16 & $\begin{array}{l}\text { BNI-AM Dana Pendapatan tetap } \\
\text { Syariah Ardhani }\end{array}$ & $-2.12 \%$ & $-6.99 \%$ & $-8.45 \%$ \\
\hline 17 & Manulife dana kas syariah & $-0.01 \%$ & $-0.08 \%$ & - \\
\hline 18 & Mandiri investa dana syariah & $-0.62 \%$ & $-4.28 \%$ & $-4.78 \%$ \\
\hline 19 & Simas syariah unggulan & $-21.76 \%$ & $-54.07 \%$ & $-51.06 \%$ \\
\hline 20 & Danareksa indeks syariah & $-19.30 \%$ & $-46.24 \%$ & - \\
\hline 21 & Mandiri investa syariah berimbang & $-2.00 \%$ & $-6.58 \%$ & $-23.38 \%$ \\
\hline 22 & Avrist balanced amar syariah & $-9.22 \%$ & $-23.08 \%$ & - \\
\hline
\end{tabular}

\section{Sumber : https://bibit.id (2020)}

Tabel di atas merupakan mengukur kinerja reksadana syariah ditinjau dari drawdown. Setiap keuntungan pasti selalu ada resikonya. Semakin besar keuntungan semakin besar pula resikonya (high return, high risk). Drawdown merupakan penurunan maksimum suatu reksadana dari titik puncak ke titik rendah, sebelum puncak baru tercapai selama periode tertentu. Drawdown adalah indikator resiko penurunan dari suatu reksadana selama jangka waktu tertentu. Drawdown yang tinggi umumnya ditemukan direksadana campuran maupun saham. Untuk sebagian besar reksadana syariah, nilai drawdown ada di angka 0 koma sekian. Bahkan tidak sedikit pula yang nilainya 0,00 persen.

Ditinjau dari drawdown $5 \quad \mathrm{Y}$ reksadana syariah yang memiliki resiko paling rendah yaitu BNI-AM Dana Lancar Syariah sebesar $-0.06 \%$, dan reksadana syariah yang memiliki resiko paling tinggi yaitu Danareksa indeks syariah sebesar $51.06 \%$. Sesuai kondisi perekonomian di era new normal, drawdown $1 \mathrm{Y}$ terendah terdapat pada reksadana syariah BNI-AM Dana Pendapatan tetap Syariah Ardhani, Manulife dana kas syariah, dan BNI-AM Dana Lancar Syariah yaitu sebesar $0,01 \%$. Drawdown $1 Y$ tertinggi terdapat pada reksadana syariah Danareksa indeks syariah sebesar $-19.30 \%$. Apabila sebuah reksadana memiliki nilai drawdown sebesar $-19.30 \%$ setahun, berarti kinerja reksadana tersebut pernah mengalami penurunan sebesar $19.30 \%$.

Total Asset Under Management (AUM)

Tabel 6. Total Asset Under Management (AUM)

\begin{tabular}{|c|c|c|c|c|c|}
\hline No & REKSADANA SYARIAH & $1 Y$ & $3 Y$ & $5 Y$ & $\sum \mathbf{A U M}$ \\
\hline 1 & $\begin{array}{l}\text { Sucorinvest Sharia Money Market } \\
\text { Fund }\end{array}$ & - & & & $3.133 \mathrm{~T}$ \\
\hline 2 & BNP Paribas Pesona Syariah & $+236.7 \mathrm{~B}$ & $+43.19 \mathrm{~B}$ & $+839.9 \mathrm{~B}$ & $839.91 \mathrm{~B}$ \\
\hline 3 & $\begin{array}{l}\text { Eastpring syariah fixed income } \\
\text { amanah kelas A }\end{array}$ & $+178.96 \mathrm{~B}$ & $+198.01 \mathrm{~B}$ & & $679.70 \mathrm{~B}$ \\
\hline 4 & Sucorinvest sharia equity fund & $+536.31 \mathrm{~B}$ & $+472.05 \mathrm{~B}$ & $+648.33 \mathrm{~B}$ & $673.303 \mathrm{~B}$ \\
\hline 5 & BNI-AM Dana Lancar Syariah & $+246.39 \mathrm{~B}$ & $+390.22 \mathrm{~B}$ & & $461.32 \mathrm{~B}$ \\
\hline 6 & Majoris sukuk negara Indonesia & $+21.36 \mathrm{~B}$ & $+58.93 \mathrm{~B}$ & & 426.934B \\
\hline 7 & $\begin{array}{l}\text { Manulife syariah sektoral amanah } \\
\text { kelas A }\end{array}$ & $+40.81 \mathrm{~B}$ & $-101.04 \mathrm{~B}$ & & $244.15 B$ \\
\hline 8 & Schroder Syariah Balanced Fund & $-75.05 \mathrm{~B}$ & $-158.72 \mathrm{~B}$ & $-169.57 \mathrm{~B}$ & $214.40 \mathrm{~B}$ \\
\hline 9 & Batavia dana saham syariah & $+34.66 \mathrm{~B}$ & $+49.86 \mathrm{~B}$ & $+151.97 \mathrm{~B}$ & $151.97 \mathrm{~B}$ \\
\hline 10 & Trim syariah saham & $+78.88 \mathrm{~B}$ & $-262.02 \mathrm{~B}$ & $-364.73 \mathrm{~B}$ & $145.553 \mathrm{~B}$ \\
\hline
\end{tabular}




\begin{tabular}{|c|c|c|c|c|c|}
\hline 11 & $\begin{array}{l}\text { Majoris pasar uang syariah } \\
\text { Indonesia }\end{array}$ & $-1.72 \mathrm{~B}$ & $-27.18 \mathrm{~B}$ & - & $124.96 \mathrm{~B}$ \\
\hline 12 & $\begin{array}{l}\text { Principal Islamic Equity Growth } \\
\text { Syariah }\end{array}$ & $+5.80 \mathrm{~B}$ & $-38.98 \mathrm{~B}$ & $-50.33 \mathrm{~B}$ & $110.44 \mathrm{~B}$ \\
\hline 13 & Schroder Dana Likuid Syariah & $-152.71 \mathrm{~B}$ & - & - & $107.27 \mathrm{~B}$ \\
\hline 14 & $\begin{array}{l}\text { Bahana MES Syariah Fund Kelas } \\
\text { G }\end{array}$ & $+47.70 \mathrm{~B}$ & $-3.30 \mathrm{~B}$ & - & $95.69 \mathrm{~B}$ \\
\hline 15 & Mandiri pasar uang syariah ekstra & $-20.41 \mathrm{~B}$ & - & - & $84.16 \mathrm{~B}$ \\
\hline 16 & $\begin{array}{l}\text { BNI-AM Dana Pendapatan tetap } \\
\text { Syariah Ardhani }\end{array}$ & $+24.20 \mathrm{~B}$ & $+49.50 \mathrm{~B}$ & - & $82.45 \mathrm{~B}$ \\
\hline 17 & Manulife dana kas syariah & $+36.21 \mathrm{~B}$ & - & - & $73.45 \mathrm{~B}$ \\
\hline 18 & Mandiri investa dana syariah & $+12.13 \mathrm{~B}$ & $+22.85 \mathrm{~B}$ & $+71.69 \mathrm{~B}$ & $71.69 \mathrm{~B}$ \\
\hline 19 & Simas syariah unggulan & $+4.29 \mathrm{~B}$ & $-5.13 \mathrm{~B}$ & $-137.16 \mathrm{~B}$ & $59.29 B$ \\
\hline 20 & Danareksa indeks syariah & $+12.48 \mathrm{~B}$ & $-15.17 \mathrm{~B}$ & $+41.82 \mathrm{~B}$ & $4.82 \mathrm{~B}$ \\
\hline 21 & Mandiri investa syariah berimbang & $+1.25 \mathrm{~B}$ & $+4.41 \mathrm{~B}$ & - & $36.38 \mathrm{~B}$ \\
\hline 22 & Avrist amar balanced amar syariah & $+696.43 \mathrm{M}$ & $-5.60 \mathrm{~B}$ & $-35.11 \mathrm{~B}$ & $22.28 \mathrm{~B}$ \\
\hline
\end{tabular}

\section{Sumber : https://bibit.id (2020)}

Ditinjau dari pertumbuhan Asset Under Management (AUM) 5Y, yang mengalami pertumbuhan paling tinggi yaitu BNP Paribas Pesona Syariah sebesar +839.9B, selanjutnya reksadana syariah Sucorinvest sharia equity fund sebesar +648.33B, dan reksadana syariah Batavia dana saham syariah sebesar $+151.97 \mathrm{~B}$. Pada saat era new normal ditinjau berdasarkan pertumbuhan Asset Under Management (AUM) 1Y, mayoritas sampel reksadana syariah mengalami pertumbuhan yang positif.
Reksadana syariah yang paling tinggi pertumbuhannya adalah Sucorinvest sharia equity fund, mengalami peningkatan sebesar +536.31B. Selanjutnya ada reksadana syariah BNI-AM Dana Lancar Syariah, mengalami pertumbuhan sebesar $+246.39 \mathrm{~B}$, dan Eastpring syariah fixed income amanah kelas A mengalami pertumbuhan sebesar $+178.96 \mathrm{~B}$.

\section{Net Asset Value (NAV)}

Tabel 7. Net Asset Value (NAV)

\begin{tabular}{clcccc}
\hline NO & REKSADANA SYARIAH & IY & $\mathbf{3 Y}$ & $\mathbf{5 Y}$ & NAV \\
\hline 1 & $\begin{array}{l}\text { Sucorinvest Sharia Money Market } \\
\text { Fund }\end{array}$ & +65.28 & - & $1,191.1800$ \\
\hline 2 & BNP Paribas Pesona Syariah & +352.95 & -250.84 & -95.88 & $2,267.5800$ \\
\hline 3 & $\begin{array}{l}\text { Eastpring syariah fixed income } \\
\text { amanah kelas A }\end{array}$ & +134.15 & +267.70 & - & $1,313.1200$ \\
\hline 4 & Sucorinvest sharia equity fund & +781.08 & +350.76 & $+1,027.21$ & $1,928.6200$ \\
\hline 5 & BNI-AM Dana Lancar Syariah & +66.51 & +209.85 & +352.16 & $1,567.2100$ \\
\hline 6 & Majoris sukuk negara Indonesia & +127.83 & +211.85 & - & $1,249.2801$ \\
\hline 7 & $\begin{array}{l}\text { Manulife syariah sektoral amanah } \\
\text { kelas A }\end{array}$ & +753.65 & -441.64 & -223.51 & $3,362.1100$ \\
\hline 8 & Schroder Syariah Balanced Fund & +186.44 & -79.80 & +110.62 & $2,406.8300$ \\
\hline 9 & Batavia dana saham syariah & +217.26 & -278.23 & -204.25 & $1,657.8200$ \\
\hline 10 & Trim syariah saham & +370.22 & +82.39 & +196.09 & $1,797.7200$ \\
\hline 11 & Majoris pasar uang syariah Indonesia & +38.01 & +155.78 & - & $1,174.0964$ \\
\hline
\end{tabular}




\begin{tabular}{|c|c|c|c|c|c|}
\hline 12 & $\begin{array}{l}\text { Principal Islamic Equity Growth } \\
\text { Syariah }\end{array}$ & +106.01 & -279.26 & -282.03 & $1,164.7100$ \\
\hline 13 & Schroder Dana Likuid Syariah & +25.65 & - & - & $1,046.8847$ \\
\hline 14 & Bahana MES Syariah Fund Kelas G & +119.13 & +252.48 & - & $1,347.9700$ \\
\hline 15 & Mandiri pasar uang syariah ekstra & +40.58 & - & - & $1,098.9085$ \\
\hline 16 & $\begin{array}{l}\text { BNI-AM Dana Pendapatan tetap } \\
\text { Syariah Ardhani }\end{array}$ & +163.00 & +340.60 & - & $1,416.3400$ \\
\hline 17 & Manulife dana kas syariah & +46.98 & - & - & $1,146.5000$ \\
\hline 18 & Mandiri investa dana syariah & +225.80 & +506.52 & +822.31 & $3,861.8300$ \\
\hline 19 & Simas syariah unggulan & +22.20 & -577.33 & -319.18 & 604.2747 \\
\hline 20 & Danareksa indeks syariah & +139.71 & -625.90 & -477.08 & $2,310.9000$ \\
\hline 21 & Mandiri investa syariah berimbang & +225.86 & +425.16 & - & $3,458.6600$ \\
\hline 22 & Avrist balanced amar syariah & +65.00 & +4.66 & +35.60 & $1,008.1400$ \\
\hline
\end{tabular}

Sumber : https://bibit.id (2020)

Ditinjau dari pertumbuhan Net Asset Value (NAB) 5Y, yang mengalami pertumbuhan paling tinggi yaitu Sucorinvest sharia equity fund sebesar $+1,027.21$, Mandiri investa dana syariah sebesar +822.31, dan BNI-AM Dana Lancar Syariah sebesar +352.16 . Pada saat era new normal ditinjau berdasarkan pertumbuhan Net Asset Value (NAB) 1Y, mayoritas sampel reksadana syariah mengalami pertumbuhan yang positif. Reksadana syariah yang paling tinggi pertumbuhannya adalah Sucorinvest sharia equity fund sebesar +781.08 , Manulife syariah sektoral amanah kelas A +753.65 , dan Trim syariah saham +370.22 .

\section{KESIMPULAN}

Reksadana merupakan salah satu jenis investasi pilihan yang sedang berkembang di Indonesia, meskipun masih terjadi pandemi covid 19 eksistensi kinerja reksadana syariah tumbuh positif pada era new normal. Hal itu dapat dilihat berdasarkan :

1. Tingkat return reksadana positif Compound Annual Growth Rate (CAGR), dimana dalam Compound Annual Growth Rate (CAGR) 1Y peningkatan paling tinggi sebesar $+63.97 \%$ dan paling rendah $+2.59 \%$

2. Tingkat kerugian yang paling tinggi ditinjau dari drawdown 1Y paling rendah yaitu sebesar $0,01 \%$ dan drawdown tertinggi sebesar $-19.30 \%$.

3. Terdapat peningkatan jumlah dana yang dikelola ditinjau dari nilai AUM (Asset Under Management) $1 \mathrm{Y}$ pertumbuhan paling tinggi $+536.31 \mathrm{~B}$ dan penurunan paling rendah $-152.71 \mathrm{~B}$.

4. Perttumbuhan nilai pasar reksadana saat ini, ditinjau dari Net Asset Value (NAV) $1 Y$ seluruh sampel tumbuh positif dengan tambahan paling tinggi sebesar +753.65 , dan paling rendah +22.20 . Kinerja reksadana bisa didapatkan melalui laporan prospectus dan fun fact sheet yang akan diterbitkan reksadana syariah pada periode tertentu. Tidak dianjurkan berinvestasi reksadana hanya memperhatikan isu atau berita yang berkembang dan juga hanya mengandalkan aspek emosional.

\section{DAFTAR PUSTAKA}

Bitomo, Habib \& Muharam, Harjum. 2016. Analisis Faktor-Faktor yang Mempengaruhi Kinerja Reksa Dana di Indonesia (Studi Empiris Pada Reksa Dana Konvensional di Indonesia Periode 2012-2014). Journal of Management, 5 (2), p. 114.

Endraswati, Hikmah. 2016. Islamic Ethical Invesment. LP2M-Press IAIN Salatiga. 
Hamzah, Amal., \& Yohanes, A. 2014. Analisis Perbandingan Kinerja Reksadana Syariah dengan Rekadana Konvensional Jenis Saham. Jurnal MIX, 4(3), p. 396-409.

Hariyani, Iswi dan Serfianto. 2010. Buku Pintar Hukum Bisnis Pasar Modal. Visi Media. Jakarta.

Idris, Muhammad. 2020. Cara Mudah Memilih Reksadana untuk Pemula. Di kutip dari https://money.kompas.com/read/2020 /12/05/125642226/cara-mudah memilih-reksadana-untuk-pemula.

Kasmir. Bank Dan Lembaga Keuangan Lainnya. 2013. Rajawali Pers. Jakarta.

Lohana, M Poonam. 2013. Performance Evaluation of Selected Mutual Funds. Pacific Business Review International, 5(7), p. 60-66.

Martalena, dan Malinda. 2011. Pengantar Pasar Modal. Edisi Pertama. Andi. Yogyakarta.

Qamruzzaman, ACMA. 2014. Comparative Study on Performance Evaluation of Mutual Fund Schemes in Bangladesh: An Analysis of Monthly Returns. Journal of Business Studies Quarterly, 5(4), p. 190-209.

Rodoni, Ahmad. 2009. Investasi Syariah. Lembaga Penelitian UIN. Jakarta

Rudiyanto. 2015. Mengenal "Fund Fact Sheet" Reksa Dana. Dikutip dari: https://edukasi.kompas.com/read/201 5/06/16/060100626/Mengenal.Fund.F act. Sheet.Reksa.Dana?page $=$ all.

Sutedi Adrian. 2011. Pasar Modal Syariah Sarana Investasi Keuangan; Berdasarkan Prinsip-prinsip Syariah. Sinar Grafika. Jakarta.

Syafrida, Ida., Aminah, Indianik., \& Waluyo, Bambang. 2014. Perbandingan Kinerja Instrumen Investasi Berbasis Syariah dengan Konvensional pada
Pasar Modal di Indonesia. Jurnal AlIqtishad, 6(2), p. 195-206. 